\title{
PERBEDAAN JUMLAH KOLONI STAPHYLOCOCCUS AUREUS PADA BEBERAPA KONSENTRASI PERASAN BUAH BELIMBING WULUH SECARA IN VITRO
}

\author{
K Dwi Septini ${ }^{1}$., I G Sudarmanto ${ }^{2}$., I N Mastra ${ }^{3}$
}

\begin{abstract}
Plants bilimbi (Averrhoa bilimbi Linn) has been utilized by the public as a traditional medicinal plants to cure various diseases. The content of natural chemicals from bilimbi fruits are known to have an antibacterial effect, namely, flavonoids and phenols. Methicillin Resistant Staphylococcus aureus (MRSA) is a gram-positive bacteria resistant to antibiotics semisintesis. This research aims to identify the differences in the number of colonies of Staphylococcus aureus bacteria at some concentrations of bilimbi fruit filtrate in vitro. The design of the research is a post test only control group design. Measurement of the activity of bacteria using a colony counter with dilution method. The average number of colonies of Staphylococcus aureus bacteria that grow at a concentration of bilimbi fruit filtrate $10 \%$ as much as $59.33 \times 10^{8} \mathrm{CFU} / \mathrm{ml}$; at a concentration of $20 \%$ as much as $1.33 \times 10^{8} \mathrm{CFU} / \mathrm{ml}$; at a concentration of 30\%, 40\% and 50\% contained no bacterial colonies growing. At a concentration of $10 \%$ is able to inhibit the growth of Staphylococcus aureus bacteria, while at a concentration of $30 \%$ has been able to kill the bacteria Staphylococcus aureus. There is a difference in the number of bacterial colonies of Staphylococcus aureus in some bilimbi fruit filtrate concentration (Averrhoa bilimbi Linn) in vitro $(p=0.000<0.05$ ).
\end{abstract}

Keywords: bilimbi fruit; colonies; concentration; Staphylococcus aureus

\section{PENDAHULUAN}

Indonesia merupakan negara yang memiliki keanekaragaman hayati yang tentunya juga kaya akan tanaman obat tradisional. Terdapat sekitar 30.000 jenis tanaman obat tradisional, namun kurang dimanfaatkan secara optimal, karena hanya sekitar 1.200 tanaman yang diteliti sebagai tanaman obat tradisional ${ }^{1}$. Salah satu tanaman yang telah lama dimanfaatkan sebagai obat tradisional oleh masyarakat adalah tanaman belimbing wuluh (Averrhoa bilimbi Linn) ${ }^{2}$.

Tanaman belimbing wuluh (Averrhoa bilimbi Linn) telah dimanfaatkan masyarakat sebagai tanaman obat tradisional untuk menyembuhkan berbagai penyakit. Bagian dari tanaman belimbing wuluh yang dimanfaatkan sebagai obat tradisional adalah bagian batang, daun, bunga dan buahnya. Kandungan bahan kimia alami dari buah belimbing wuluh yang diketahui mempunyai efek antibakteri yaitu, flavonoid dan fenol ${ }^{3}$. Sari buah belimbing wuluh bersifat efektif sebagai antibakteri terhadap bakteri Eschericia coli, Salmonella sp dan Staphylococcus aureus $^{4}$.

\footnotetext{
$\overline{1 ., 2.3 . \text {., Jurusan Analis Kesehatan Poltekkes Denpasar }}$ Korespondensi : K Dwi Septini ${ }^{1}$, Jurusan Analis Kesehatan, Poltekes Denpasar, Jalan Sanitasi No. 1 Sidakarya, Denpasar-Bali 80224, Indonesia. Telp. +62-361-710 527, Fax. +62-361-710 448 Email : meditoryjournal@gmail.com
} 
Staphylococcus aureus merupakan bakteri berbentuk bulat yang dapat menginfeksi jaringan atau alat tubuh lain yang menyebabkan timbulnya penyakit dengan tanda-tanda yang khas seperti nekrosis, peradangan dan pembentukan abses $^{5}$. Methicillin

Resistant Staphylococcus aureus (MRSA) yang merupakan bakteri gram positif yang resistan terhadap antibiotik semisintesis. Berdasarkan uraian diatas penulis tertarik meneliti perbedaan jumlah koloni Staphylococcus aureus pada beberapa konsentrasi perasan buah belimbing wuluh (Averrhoa bilimbi) secara in vitro. Pemilihan perasan buah belimbing wuluh sebagai alternatif pencegahan penyakit akibat infeksi bakteri Staphylococcus aureus karena mudah diperoleh, tersedia dalam jumlah yang banyak dan pengaplikasiannya yang mudah di masyarakat.

\section{METODE}

Jenis penelitian yang digunakan adalah penelitian true-experimental dengan rancangan penelitian adalah post test only control group design. Penelitian ini dilaksanakan di Laboratorium Mikrobiologi Fakultas Kedokteran Universitas Udayana pada bulan JanuariJuni 2016.

Dalam penelitian ini dilakukan tiga kali pengulangan dan dua kali replikasi, sehingga diperoleh sebanyak 30 data.
Penelitian ini menggunakan kontrol positif yaitu suspensi bakteri Staphylococcus aureus dan kontrol negatif yaitu aquadest steril.

Metode uji yang digunakan adalah metode dilusi dengan menghitung jumlah koloni bakteri yang tumbuh pada media menggunakan colony counter. Konsentrasi perasan buah belimbing wuluh yang digunakan yaitu 10\%, 20\%, 30\%, 40\% dan $50 \%$. Adapun cara kerjanya adalah buah belimbing wuluh yang segar ditimbang sebanyak 500 gram kemudian dicuci, dihaluskan dan diperas dengan kasa steril sehingga diperoleh perasan buah belimbing wuluh 100\%. Setelah itu diencerkan dengan rumus $\mathrm{V} 1 \quad \mathrm{x} \quad \mathrm{N} 1=\mathrm{V} 2 \quad \mathrm{x} \quad \mathrm{N} 2$ sehingga didapat konsentrasi 10\%, 20\%, $30 \%$, $40 \%$ dan $50 \%$ seperti pada tabel dibawah ini:

\begin{tabular}{|c|c|c|c|c|c|}
\hline No & $\begin{array}{c}\mathrm{V} 1 \\
(\mathrm{ml})\end{array}$ & $\mathrm{C} 1$ & $\begin{array}{c}\mathrm{V} 2 \\
(\mathrm{ml})\end{array}$ & $\mathrm{C} 2$ & $\begin{array}{c}\text { Aquadest } \\
\text { Steril } \\
(\mathrm{ml})\end{array}$ \\
\hline 1 & 0,5 & $100 \%$ & 5 & $10 \%$ & 4,5 \\
\hline 2 & 1 & $100 \%$ & 5 & $20 \%$ & 4 \\
\hline 3 & 1,5 & $100 \%$ & 5 & $30 \%$ & 3,5 \\
\hline 4 & 2 & $100 \%$ & 5 & $40 \%$ & 3 \\
\hline 5 & 2,5 & $100 \%$ & 5 & $50 \%$ & 2,5 \\
\hline
\end{tabular}

Keterangan:

$\mathrm{V}_{1}$ : volume perasan buah belimbing wuluh konsentrasi $100 \%$ yang akan diencerkan. 
K Dwi Septini, dkk., Perbedaan Jumlah Koloni Staphylococcus aureus Pada Beberapa Konsentrasi Perasan Buah Belimbing Wuluh Secara In Vitro

$\mathrm{V}_{2}$ : volume perasan buah belimbing wuluh yang akan dibuat yaitu $5 \mathrm{ml}$.

$\mathrm{C}_{1}$ : konsentrasi perasan buah belimbing wuluh yang akan diencerkan yaitu konsentrasi $100 \%$.

$\mathrm{C}_{2}$ : konsentrasi perasan buah belimbing wuluh yang akan dibuat.

Kemudian dilakukan pengerjaan sampel dengan cara setiap tabung diisi dengan $0,1 \mathrm{ml}$ perasan buah belimbing wuluh kemudian ditambahkan suspensi bakteri Staphylococcus aureus sebanyak $10 \mu \mathrm{l}$ dan dihomogenkan. Campuran suspensi bakteri dengan perasan buah belimbing wuluh diambil sebanyak satu ose kemudian diinokulasikan pada media Blood Agar Plate. Media Blood Agar Plate diinkubasi pada suhu $37^{\circ} \mathrm{C}$ selama 24 jam. Setelah 24 jam dilakukan pengamatan terhadap adanya koloni yang tumbuh pada masing-masing petri baik kontrol maupun sampel kemudian dihitung rata-rata koloni tersebut dengan menggunakan colony counter.

Jenis data yang dikumpulkan adalah data primer, yang didapat dari hasil eksperimen di laboratorium yang berupa jumlah koloni Staphylococcus aureus pada masing-masing plate yang dihitung menggunakan colony counter. Data yang diperoleh kemudian diolah menggunakan teknik pengolahan data dan disajikan dalam bentuk tabel dan narasi. Analisis data dilakukan dengan menggunakan uji statistik menggunakan Uji Kolmogorov Smirnov untuk mengetahui data berdistribusi normal atau tidak. Apabila data berdistribusi normal dilanjutkan dengan uji One Way Anova sedangkan apabila data berdistribusi tidak normal dilanjutkan dengan uji Kruskal Wallis $^{6}$.

\section{HASIL DAN PEMBAHASAN}

Data yang diperoleh dari hasil perhitungan jumlah koloni Staphylococcus aureus pada beberapa konsentrasi perasan buah belimbing wuluh (Averrhoa bilimbi Linn) dapat dilihat pada tabel 1 dibawah ini:

Tabel 1. Rerata Jumlah Koloni Staphylococcus aureus Pada Beberapa Konsentrasi Perasan Buah Belimbing Wuluh (Averrhoa bilimbi Linn)

\begin{tabular}{|c|c|c|c|}
\hline \multirow[t]{2}{*}{$\begin{array}{c}\text { Perlakuan } \\
\text { Konsentrasi }\end{array}$} & \multicolumn{2}{|c|}{$\begin{array}{c}\text { Rerata Jumlah } \\
\text { Koloni per } \\
\text { Replikasi }\left(10^{8}\right. \\
\text { CFU/ml) }\end{array}$} & $\begin{array}{c}\text { Rerata } \\
\text { Seluruh } \\
\text { Replikasi } \\
\quad\left(10^{8}\right.\end{array}$ \\
\hline & I & II & $\mathrm{CFU} / \mathrm{ml})$ \\
\hline $\begin{array}{l}\text { Kontrol } \\
\text { Negatif }\end{array}$ & \multicolumn{2}{|c|}{0} & 0 \\
\hline $\begin{array}{c}\text { Kontrol } \\
\text { Positif }\end{array}$ & \multicolumn{2}{|c|}{315} & 315 \\
\hline $10 \%$ & 31,67 & 87 & 59,33 \\
\hline $20 \%$ & 0 & 1,33 & 1,33 \\
\hline $30 \%$ & 0 & 0 & 0 \\
\hline $40 \%$ & 0 & 0 & 0 \\
\hline $50 \%$ & 0 & 0 & 0 \\
\hline
\end{tabular}




\section{Analisis Data}

Hasil uji Kolmogorov Smirnov didapatkan nilai probabilitas $0,000<\alpha$ $(0,05)$ untuk data jumlah koloni, sehingga dapat disimpulkan bahwa data yang didapat berdistribusi tidak normal. Dilanjutkan dengan uji Kruskal Wallis diperoleh nilai probabilitas $(0,000)<\alpha$ $(0,05)$ yang menandakan bahwa ada perbedaan jumlah koloni bakteri Staphylococcus aureus pada beberapa konsentrasi perasan buah belimbing wuluh (Averrhoa bilimbi Linn). Uji Mann Whitney menunjukkan ada perbedaan yang bermakna antara masing-masing konsentrasi perasan buah belimbing wuluh (Averrhoa bilimbi Linn) yang ditunjukkan dengan nilai probabilitas $(0,002)<\alpha$ $(0,05)$.

\section{Pembahasan}

Berdasarkan hasil penelitian dapat diketahui bahwa kontrol negatif yang digunakan berupa aquadest steril tidak menunjukkan pertumbuhan koloni bakteri Staphylococcus aureus. Kontrol positif yang digunakan berupa suspensi bakteri Staphylococcus aureus menunjukkan ratarata jumlah pertumbuhan koloni bakteri yakni sebanyak 315 x $10^{8} \mathrm{CFU} / \mathrm{ml}$.

Rata-rata jumlah koloni bakteri Staphylococcus aureus yang tumbuh pada media Blood Agar Plate dengan konsentrasi $10 \%$ dan $20 \%$ dalam tiga kali pengulangan dan dua kali replikasi adalah sebesar 59,33 x $10^{8} \mathrm{CFU} / \mathrm{ml}$ dan $1,33 \times 10^{7}$ $\mathrm{CFU} / \mathrm{ml}$. Hasil tersebut menunjukkan penurunan yang signifikan jika dibandingkan dengan jumlah koloni bakteri yang tumbuh pada kontrol positif yaitu sebesar 315 x $10^{8} \mathrm{CFU} / \mathrm{ml}$. Hasil ini menunjukkan bahwa perasan buah belimbing wuluh dengan konsentrasi $10 \%$ dan $20 \%$ sudah mampu menghambat pertumbuhan bakteri Staphylococcus aureus. Sedangkan jumlah koloni bakteri Staphylococcus aureus pada konsentrasi $30 \%$, 40\% dan 50\%, menunjukkan hasil bahwa tidak terdapat bakteri yang tumbuh pada media Blood Agar Plate.

Penurunan jumlah koloni disebabkan oleh kandungan zat aktif dalam buah belimbing wuluh yang bersifat antibakteri. Buah belimbing wuluh mengandung saponin, flavonoid, alkaloid, dan triterpenoid $^{7}$. Saponin merupakan zat aktif yang dapat meningkatkan permeabilitas membran sehingga terjadi hemolisis sel. Flavonoid merupakan kelompok senyawa fenol yang mempunyai kecenderungan untuk mengikat protein sehingga mengganggu proses metabolisme ${ }^{8}$. Alkaloid indol memilki aktifitas antibakteri dari Aspidosperma ramiflorum ${ }^{9}$. Senyawa golongan triterpenoid menunjukkan aktivitas farmakologi yang signifikan, seperti antiviral, antibakteri, antiinflamasi, sebagai inhibisi terhadap sintesis kolesterol dan sebagai antikanker ${ }^{10}$. 
K Dwi Septini, dkk., Perbedaan Jumlah Koloni Staphylococcus aureus Pada Beberapa Konsentrasi Perasan Buah Belimbing Wuluh Secara In Vitro

Berdasarkan hasil penelitian yang sudah dilakukan perasan buah belimbing wuluh mempunyai daya hambat dan daya bunuh bakteri yang sangat baik. Perasan buah belimbing wuluh dengan konsentrasi $10 \%$ sudah mampu menghambat pertumbuhan bakteri Staphylococcus aureus. Pada konsentrasi 30\% sudah mampu membunuh bakteri Staphylococcus aureus.

\section{SIMPULAN DAN SARAN Simpulan}

Ada perbedaan jumlah koloni bakteri Staphylococcus aureus pada konsentrasi 10 dan $20 \%$ perasan buah belimbing wuluh (Averrhoa bilimbi Linn) secara in vitro $(p=0,000<0,05)$.

\section{Saran}

Peneliti lain disarankan untuk melakukan penelitian lebih lanjut dengan mengujikannya pada jenis bakteri lain seperti bakteri gram negatif. Selain itu penelitian ini juga dapat dikembangkan dengan melakukan penelitian secara in vivo. Kepada masyarakat diharapkan dapat memanfaatkan buah belimbing wuluh untuk mencegah infeksi yang disebabkan oleh bakteri Staphylococcus aureus.

\section{DAFTAR PUSTAKA}

1. Candra, S. 2012. Pengaruh Pemberian Ekstrak Buah Belimbing Wuluh ( Averrhoa Blimbi L. ) Terhadap Penurunan Kadar Glukosa Darah
Tikus Wistar Yang Diinduksi Aloksan. Karya Tulis Ilmiah. Fakultas Kedokteran Universitas Diponegoro. Semarang. (online). available: http://core.ac.uk/download/files/379/1 1736092.pdf (diakses pada tanggal 18 Januari 2016).

2. Lathifah, Q. A. 2008. Uji Efektifitas Ekstrak Kasar Senyawa Antibakteri Pada Buah Belimbing Wuluh (Averrhoa Bilimbi L.) dengan Variasi Pelarut. Skripsi. Jurusan Kimia Fakultas Sains Dan Teknologi Universitas Islam Negeri (UIN) Malang.

3. Prayogo, Boedi S. R, RenaW. P. 2011. Uji Potensi Sari Buah Belimbing Wuluh (Averrhoa bilimbi L.) dalam Menghambat Pertumbuhan Bakteri Aeromonas salmonicida smithia Secara In Vitro. Jurnal Penelitian. Fakultas Perikanan dan Kelautan Universitas Airlangga. Surabaya. (online). available: http:// http://undana.ac.id/jsmallfib_top/JUR NAL/PERIKANAN/PERIKANAN\%2 02011/UJI\%20POTENSI\%20SARI\%2 0BUAH\%20BELIMBING\%20WULU H\%20(Averrhoa\%20bilimbi\%20L.)\% 20DALAM.pdf (diakses pada tanggal 18 Januari 2016).

4. Oktavianes, Mades F., Dezi H. 2013. Daya Hambat Sari Buah Belimbing Wuluh (Averrhoa Bilimbi, L) 
K Dwi Septini, dkk., Perbedaan Jumlah Koloni Staphylococcus aureus Pada Beberapa Konsentrasi Perasan Buah Belimbing Wuluh Secara In Vitro

Terhadap Pertumbuhan Bakteri

Eschericia Coli. Program Studi

Pendidikan Biologi STKIP PGRI

Sumatera Barat Jurusan Biologi

Universitas Negeri Padang.

5. Lauma, S. W., Pangemanan, Damajanty H. C., Hutagalung, Bernart S.P. 2015. Uji Efektifitas Perasan Air Jeruk Nipis (Citrus aurantifolia S) Terhadap Pertumbuhan Bakteri Staphylococcus aureus Secara in Vitro. Jurnal Penelitian. Program Studi Pendidikan Dokter Gigi Fakultas Kedokteran Bagian Fisiologi Fakultas Kedokteran UNSRAT. (online). available:http://ejournal.unsrat.ac.id/in dex.php/pharmacon/article/download/. ..$/ 9772$ (diakses pada tanggal 20 Januari 2016).

6. Notoatmodjo, S. 2012. Metodologi Penelitian Kesehatan. Edisi Revisi. Jakarta: PT. Rineka Cipta.

7. Yuliandari, R. 2015. Uji Aktivitas Antibiofilm Sari Buah Belimbing Wuluh (Averrhoa bilimbi L) terhadap
Biofilm Pseudomonas aeruginosa secara In Vitro. Skripsi. Program Studi Farmasi. Fakultas Kedokteran dan Ilmu Kesehatan. Universitas Islam Negri Syarif Hidayatullah

8. Ganiswara, G. S. 1995. Farmakologi dan Terapi. Ed. IV. Fakultas Kedokteran Bagian Farmakologi. Universitas Indonesia. Jakarta.

9. Tanaka, J.C.A. C.C. da Silva, A.J.B. de Oliveira, C.V. Nakamura and B.P. Dias Filho. 2006. Antibacterial activity of indole alkaloids from Aspidosperma ramiflorum. Antimicrobial activity of A. ramiflorum Brazilian Journal of Medical and Biological Research.

10. Nassar, Zeyad., dan Abdalrahim, Amin M.S. 2010. The Pharmacological Properties of terpenoid from Sandoricum Koetjape. Journal Medcentral, 2010, 111. 